\title{
Study of Government Public Service Satisfaction - A Case of Xinjiang Awat County
}

\author{
Yin Chen ${ }^{1, a}$, Aiping Zhang ${ }^{2, b}$ \\ ${ }^{12}$ College of Economics and Management, Tarim University, Alar, XinJiang, 843300 \\ ${ }^{\mathrm{a}}$ email, ${ }^{\mathrm{b}}$ email
}

Keywords: Xinjiang Awat; Public Services; Public Satisfaction; Policies

\begin{abstract}
Harmonious society emphasizes people-oriented, public service which requires the government should give priority to the public, and effectively improve public satisfaction with the government's public service. Eighteen people called for the construction of satisfactory service-oriented government, public satisfaction with the value orientation of public service as the main building. In county government as a direct subject of public service, public service satisfaction provided by their local government can be a direct reflection of the level of supply and the capacity of public services. In this paper, Xinjiang Awat County as an object of study, in reference to the relevant research results at the same time, combined with the actual situation Awat County, the government's public service satisfaction of Xinjiang Awat County were studied. This paper is divided into five parts: The first part of the introduction to the current public service satisfaction background is analyzed; the second part analyzes the factors that influence the government's public service satisfaction; third section presents several Xinjiang Ava on Strengthening mention government public service satisfaction strategies; fourth section describes the significance of the government's public service satisfaction; part V Conclusion of paper summarized. In this, I hope that through this study will enable us to better grasp the factors that influence the government public service public satisfaction, and explore the best way to truly improve public satisfaction, people are satisfied with the construction of service-oriented government.
\end{abstract}

\section{Introduction}

As society advances, more and more countries have begun to attach importance to improve public services, emphasizing the construction of people's satisfaction with service-oriented government. From the reform and opening up, our government public service capacity has been greatly improved, but there is a big gap between different regions, Xinjiang Uygur Autonomous Region of Xinjiang Wa Erti County is located in the Midwest, our cotton and grain is an important production base its study government public service satisfaction will have important practical significance. At the same time, in 2012 the CCP 18th Party Congress "Science building functions, structural optimization, clean and efficient, people are satisfied with the service-oriented government," the goal is presented, which further clarified the function of our government will be changed from Public Economy Oriented Government service-oriented government, in order to effectively improve the government's public service levels, improve people's satisfaction with the government's public service, we are very necessary to the relevant factors of the government public service are analyzed to find an effective way to improve the government's public service satisfaction.

\section{A public service public satisfaction influencing factors}

Economic Development Factors. In general, the supply of public services will be largely satisfied with the improvement of per capita levels of economic development and an increase in per capita public expenditure increases. Economic development as the government increased the supply of public services on the basis of, and therefore in the development of the economy, the government in public services must take full account of the standard value per capita, increasing per capita rights enjoyed by public service resources. Seen in this light, because of the economic development factors in promoting local economic development and improvement of the economic level of per 
capita and per capita public expenditure and can effectively improve the government's public service satisfaction.

Government building factor. From the point of view of the factors affecting economic development, to a certain extent, per capita and per capita economic level of public expenditure and the public on government's public service satisfaction is that with the development. But when the economy develops to a certain stage, the public service of the government improved public will not only be limited to the supply of public services, they need more of a multi-level, multi-dimensional public service of. Therefore, the government itself whether to establish a multi-level, multi-dimensional public service system will be directly related to the public on the government's public service satisfaction.

Individual Factors residents. Depending on individual differences in gender, age, education, occupation, income and other aspects, so that the residents of individual differences in cognitive thinking, there are differences on the government's public service satisfaction. Different individuals in the public service government has different needs, the government's public service satisfaction will vary. Therefore, the Government should consider the provision of public services are individual differences inhabitants, construction diversified, multi-level service system, so to meet the different needs of different groups when the allocation of public resources.

\section{The Mehod to Improve the Public Satisfaction of Government's Public Service}

Improve the government's public service funding mechanism. To continue to use the central government on the Xinjiang government support funds, increase investment in public services Awat County of Xinjiang government to subsidize financial shortage due to higher costs caused by the public service. For example, to increase investment in Awat County roads and water conservancy projects, which require funds to ensure the smooth progress of road construction and hydraulic engineering. Therefore, to establish a perfect government public service funding mechanism, which is not only related to the Huimin implementation of government measures, but also to the public to improve the government's public service satisfaction.

Improve the government's public service business level. Government public service is not only influenced by the corresponding hardware facilities, the ability of civil servants own quality of public service also has a great relationship. Therefore, to improve the financial security mechanism of public services at the same time, we also need to improve public services, optimize the allocation of social resources, strengthen the training of public services, improve business professional level of public services. For example, in order to provide better public services, when the government when there are new services, we will provide timely training for civil servants, to provide timely service to the public.

Regularly evaluate the performance of public services. Public services to evaluate the performance, not just for the public service element of performance evaluation, but also to respond to different villages Awat County, the different services project evaluation, assessment of the effect given to encourage and reward good, the bad effects assessment criticism and rectification. Civil service as a direct provider of public services, performance evaluation of its services, not only can improve the motivation of civil servants, but also to promote the upgrading of the level of public services, increase public satisfaction with government public services. Public services in different villages of the overall assessment that allows different villages from each other and stimulate competition between the different indicators of public service village, effectively improve the government's public service.

Establish and improve the government's public service feedback mechanism. In order to grasp the effect of public services provided by the Government to establish a sound mechanism for feedback is crucial public services. Therefore, the strengthening of government information disclosure and feedback, to allow more public participation in the government's public service competent supervision, improve the government's public service feedback mechanism. For example, vigorously promote Awat County telephone feedback online feedback, so that everyone is able to feedback their wishes, so that energy is a service provided by the Government to be more in line 
with public demand, and secondly, can effectively meet the public's wishes increase public satisfaction with government public services.

\section{Improve the Significance of the Government's Public Service Satisfaction}

When the various countries in the world the importance of improving public service satisfaction when our public services satisfaction is not only to meet the needs of social development, which itself has a lot of practical significance, which is embodied in the following aspects:

Improve public service satisfaction will help improve the government's public service levels, improve the government's ability to govern. Ours is a Chinese Communist Party led the people's democratic dictatorship of socialist state, improve public services, satisfaction, to maximize the public interest, not only to enhance the government's public service levels, but also effectively improve the government's ability to govern. For example, for Awat county medical institutions perfect time, improve service levels and supply services of medical institutions, so let the public enjoy more health benefits increased public satisfaction with government public services, but also to medical institutions, large-scale development of services, improving the government's ability to govern.

Ours is a people's democratic dictatorship of socialist state, true democracy to do, then we must understand what the public really needed Yes. Government to improve their level of public services, when, to increase public satisfaction with the service, oh, it must effectively understand the public's wishes and needs, and it was in line with the requirements of our democracy. At the same time, when we raise the government's public service satisfaction, you can better grasp the condition of government public services, the public needs to know what is and what is public is not required, and what services do good, what services are to be improved. Therefore, improving the government's public service satisfaction when, to better meet the public's needs and improve services so that the government has been recognized by the public, in line with public expectations, greatly improving the sense of public trust in government.

The ultimate beneficiaries of the government's public service is a public, government public service quality and most persuasive voice is public, visible public government provision of public services is the dominant factor. Improving public service satisfaction when the wider public to have the opportunity to participate in government decision-making among public service, help the government to have a full understanding of the public, so that more public proposal can be adopted by the Government to improve public awareness of political participation, but also to broaden the government's political participation channels for the public to help the government improve public services better.

Today stressed people-oriented, which is in line with the requirements of harmonious social development. Public satisfaction with government's public service as one of the criteria of harmonious social development, improve the government's public service satisfaction to a large extent on the development of a harmonious society has a role in promoting. Public satisfaction with government's public service help the government improve people at all levels to better grasp the needs and wishes of the community public services, so that the Government can promptly and effectively to weaknesses in public service reform, the implementation of livelihood issues of public concern, promote the development of socialist harmonious society.

Improve the government's public service satisfaction, can the development of regional economy, local people benefit more, so that you can allow more public access to public services the government to get more benefits, secondly, to promote local economic development in while increasing local residents' sense of trust in the government to promote solidarity between the peoples of our country. For example, in Xinjiang Awat County compulsory education subsidies increase public service, so to be able to better promote the development of education in Awat County, to allow more people to master advanced scientific knowledge to promote the development and progress of the local economy, and secondly, Awat County residents increased sense of confidence in the government, promoting national unity of our country.

Conclusion: From the we can know and improve the government's public service satisfaction, 
which is not only to meet the social development of the inevitable need, which also significantly improve the government's public service levels, improve overall ability to govern; a solid understanding of public demand, increase trust in government sense; to raise public awareness of political participation, to broaden political participation government channels; livelihood issues, promote the development of a harmonious society; promote regional economic development, the promotion of national unity and other important practical significance. Therefore, we must improve the implementation of the government's public service funding mechanism; regularly evaluate the government's public service content; improve overall public services; establish and improve public service feedback mechanisms and other initiatives to improve the government's public service satisfaction in the true sense.

\section{Acknowledgements}

South Xinjiang urban and rural grassroots social governance mechanism research National Social Science Fund Project (14AZD054).

\section{References}

[1] Zhu Jinhe, Chen Yahui. factors that affect the Xinjiang government's public service supply capacity and enhance the study [J]. Reclamation Economy, 2013 (11).

[2] Liu Wu, Yang Xue. On the government's public service satisfaction measurement [J]. Journal of Northeastern University (Social Science Edition), 2006 (02).

[3] Yin Shuang, Chen Yifan. Promotion Measures of the government's public service satisfaction [J]. Law and Society, 2009 (06).

[4] Jiang Xiaojie, Zhao Chunsheng. public satisfaction survey of county government public service provision - empirical data based on a larger sample of Kaiyuan in Yunnan Province [J] administrative forum, 2013 (01).

[5] Tian Yanping. Advances in research and foreign cities Public Service Equalization [J]. Zhongnan University of Technology, 2014 (1).

[6] Mo Shenrong. Grass-roots government public satisfaction survey of Public Service - Taking Shapingba District of Chongqing City [D]. Yunnan University of Finance and Economics, 2012.

[7] Liu Fanghua. Local Government Public Service Satisfaction Impact Factors - A Case Study of Yancheng City in Jiangsu Province [D] South China University of Technology, 2014.

[8] Feng Fei, Zhong Yang. Factors Affecting China Urban Public Service of public satisfaction based on 10 city public satisfaction survey [J] Shanghai Administration Institute, 2016 (02).

[9] Lou Dongsheng, Zhang Pingping Situation and Promotion Countermeasure Service Government Building trust in government. View of the New Public Service Theory [J] Chengdu Institute of Public Administration, 2012 (06).

[10] Li Chun. The Development and Enlightenment of Urban Community Public Service Model [J]. Theory Guide, 2013 (2). 